ISSN 0103-5150

Fisioter. Mov., Curitiba, v. 30, n. 3, p. 579-585, Jul./Sep. 2017

Licenciado sob uma Licença Creative Commons

DOI: http://dx.doi.org/10.1590/1980-5918.030.003.A016

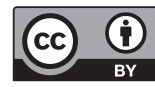

\title{
Sport injuries treated at a physiotherapy center specialized in sports
}

\section{Lesões esportivas tratadas em um centro de fisioterapia especializado em esportes}

\section{Guilherme S. Nunes $^{[\mathrm{a}, \mathrm{b}] *}$, Alessandro Haupenthal ${ }^{[a, c]}$, Manuela Karloh ${ }^{[a]}$, Valentine Zimermann Vargas ${ }^{[\mathrm{a}, \mathrm{d}]}$, Daniela Pacheco dos Santos Haupenthal ${ }^{[\mathrm{a}, \mathrm{e}]}$, Bruna Wageck ${ }^{[\mathrm{a}, \mathrm{f}] *}$}

[a] Universidade do Estado de Santa Catarina (UDESC), Florianópolis, SC, Brazil

[b] Universidade Federal de São Carlos (UFSCar), São Carlos, SP, Brazil

[c] Universidade Federal de Santa Catarina (UFSC), Araranguá, SC, Brazil

[d] Universidade Federal de São Paulo (UNIFESP), São Paulo, SP, Brazil

[e] Universidade do Extremo Sul Catarinense (UNESC), Criciúma, SC, Brazil

[f] La Trobe University, Melbourne, VIC, Australia

\begin{abstract}
Introduction: The risk of injuries related to physical activity and sports may increase if there is predisposition, inappropriate training and/or coach guidance, and absence of sports medicine follow-up. Objective: To assess the frequency of injuries in athletes treated at a physiotherapy center specialized in sports. Methods: For the data collection was carried out the survey of injuries in records of athletes treated in eight years of activities. The data collected included: characteristics of patients, sport, injury kind, injury characteristics and affected body part. Results: From 1090 patient/athlete records, the average age was 25 years old, the athletes were spread across 44 different sports modalities, being the great majority men (75\%). The most common type of injury was joint injury, followed by muscular and bone injuries. Chronic injury was the most frequent (47\%), while the most common body part injured was the knee, followed by ankle and shoulder. Among all the sports, soccer, futsal, and track and field presented the highest number of injured athletes, respectively. Conclusion: Soccer was the most common sport among the injured athletes, injury kind most frequent was joint injuries and knee was the body part most injured. Chronic injuries were the most common.
\end{abstract}

* GSN: Doctoral Student, e-mail: nunesguilherme@live.com AH: PhD, e-mail: dedsnet@yahoo.com.br MK: PhD, e-mail: manukarloh@gmail.com VZV: MS, e-mail: valentinezvargas@hotmail.com DPSH: Doctoral Student, e-mail: danisantos82@yahoo.com.br BW: Doctoral Student, e-mail: bruwageck@hotmail.com 
Nunes GS, Haupenthal A, Karloh M, Vargas VZ, Haupenthal DPS, Wageck B.

Keywords: Athletic Injuries. Soccer. Knee. Ankle.

\title{
Resumo
}

\begin{abstract}
Introdução: $O$ risco de lesões relacionadas à atividade física e ao esporte aumenta quando existe predisposição, falta de treinamento ou orientação e em atividades na qual não houve preparação adequada. Objetivo: Verificar a frequência das lesões em atletas atendidos por um serviço especializado em fisioterapia esportiva.

Métodos: Para a coleta de dados foi realizado o levantamento das lesões nos prontuários de atletas atendidos em oito anos de atividades. Foram coletados da ficha de avaliação: características dos pacientes, modalidade esportiva, tipos e características das lesões e o segmento corporal acometido. Resultados: A partir de 1090 prontuários de pacientes/atletas atendidos, a média de idade foi 25 anos, distribuídos em 44 diferentes modalidades esportivas com predomínio do sexo masculino (75\%). 0 tipo de lesão mais frequente foi a articular, seguida das musculares e ósseas. As lesões crônicas foram as mais frequentes (47\%). O local mais lesionado foi o joelho, seguido do tornozelo e ombro. Dentre as modalidades, o futebol, o futsal e o atletismo foram as que apresentaram o maior número de atletas lesionados. Conclusão: Futebol foi a modalidade mais praticada entre os atletas atendidos, o tipo de lesão mais frequente foi o articular e o joelho foi o local mais acometido, com lesões crônicas sendo as comuns.
\end{abstract}

Palavras-chave: Traumatismos em Atletas. Futebol. Joelho. Tornozelo

\section{Introduction}

In order to attain the highest performance level athletes normally have to undergo extraneous daily sports practices. Repetitive exercises and imbalance between training and recovery may be predictive factors for injuries $(1,2)$. On the other hand, moderate physical activity with no focus on high performance is important to prevent illnesses such as hypertension, diabetes type II, obesity and others $(3,4)$. Balanced physical activity is recommendable to all ages (3); and in many cases, recreational sports activities are often chosen.

Nonetheless, even recreational practitioners are not immune to sports injuries, especially if not properly guided/supervised $(1,2)$. Previous studies have indicated high incidence of injuries related to recreational sports practices and physical activities $(5,6)$. An epidemiological research in Australia assessed the number of sports-related injuries of 69.663 habitants during one year. More than 2000 recreational athletes had been seen at hospitals and clinic; according to their sample one every 32 habitants of the city was injured.

Many epidemiological studies were developed to display the frequency of injuries of different sports such as soccer (7), athletics (8), endurance running (9), surf (10) and basketball (11). These studies warrant prevention programs aiming at decreasing the frequency of occurrences and recurrence of injuries, what benefits the athletic life (professional or amateur), and allows them to even further improve their performance (12-14). Despite the effectiveness of any prevention program, sports injuries will continue to happen. Some of the risk factors are inherent to specific physical activities practices and cannot change (12). Therefore, the sports injuries treatment is a challenge that involves several professionals with a common goal: to promote the return of the injured athlete whether he or she is professional, amateur or recreational to his or her normal sports practice (15). To do so, it is important to know the most recurrent injury types as well as the profile of the athletes arriving at the clinics/ hospitals (12). This study assessed the frequency of injuries in athletes treated at a physiotherapy center specialized in sports.

\section{Methods}

This research analyzed the records from all athletes who participated in the University extension program called "Fisioterapia Desportiva" from the "Universidade do Estado de Santa Catarina (UDESC)". This program offers free physiotherapeutic care for athletes of different modalities and levels from both, the university and Florianopolis city. 
All records between 2005 and 2013 were reviewed and included in this study. An especial form created by the faculty of Physiotherapy was used as an evaluation tool. This form targets both, clinical assessment and treatment (16).

The types of injury were classified as muscular, joint, bone, and others $(17,18)$. Muscular are those that affect the muscles and the tendinous structures such as stretching injury and tendinopathies. The joint ones affect parts of the joints, such as capsules, cartilage, meniscus and ligaments. Bones are those that affect directly the bone system such as fractures and periostitis. The other ones were those that did not fit into the aforementioned types; for instance, skin and systemic diseases. The injuries were also classified according to their phase: acute (0-4 days after the traumatic event), subacute (5-14 after the traumatic event) and chronic (15 days after the traumatic event or overuse) (19). The data was described using the SPSS 17.0 program.

All the procedures were approved by the Research Ethics Committee of Santa Catarina State University (study \#157/2008).

\section{Results}

One thousand ninety profiles $(1,090)$ were analyzed; the average age of the population assessed was $25.3 \pm$ 8.3 years old; $75 \%$ were men, and $25 \%$ were women. Forty four sports modalities were found in the records. The average athletic experience was $9.5 \pm 7.4$ years, being $85 \%$ of the athletes, amateur and $15 \%$ professional.

The most frequent type of injury was the joint one $(55.5 \%)$, followed by muscular $(33.4 \%)$, bones $(9.2 \%)$, and other $(1.9 \%)$. Regarding the phases: chronic injuries were the most common $(47.0 \%)$, followed by subacute $(26.6 \%)$, and acute $(26.4 \%)$. Figure 1 displays the injuries and the respective body part affected. The least affected body parts were: pelvis (1.2\%), elbow (1.1\%), hand (1.0\%), cervical spine $(0.9 \%)$, forearm $(0.8 \%)$, thoracic spine $(0.7 \%)$, arm $(0.5 \%)$, systemic alteration $(0.4 \%)$, abdomen $(0.2 \%)$, and coccyx $(0.1 \%)$. Table 1 shows the frequency distribution of injuries from each modality. Although ankle sprain was the most frequent injury, this joint was not the most affected; the most frequent injuries are tendinopathies, anterior cruciate ligament rupture, muscular injury, and meniscal injury (Table 1).

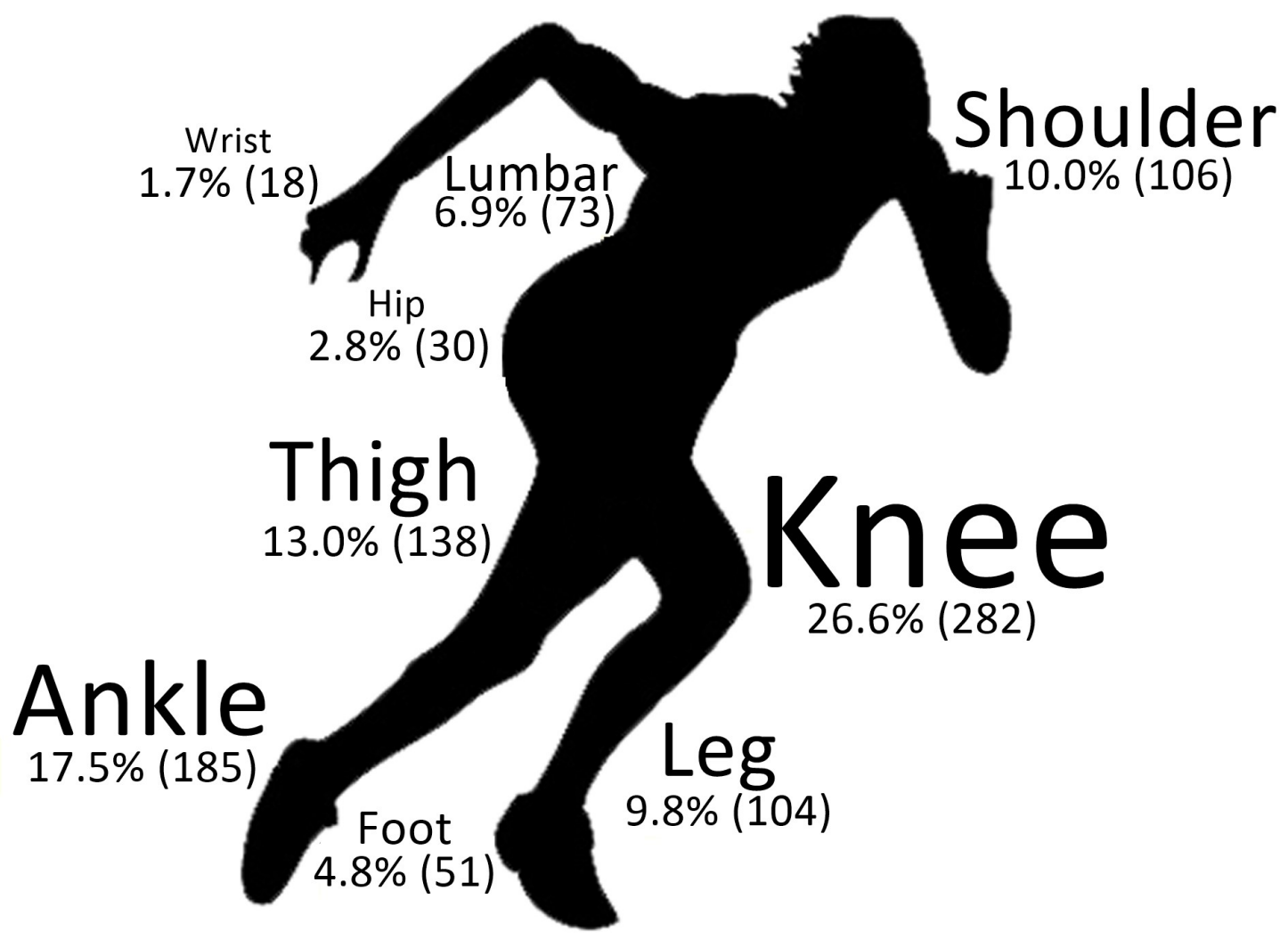

Figure $\mathbf{l}$ - Incidence of of injuries per body part.

Fonte : authors. 
Table 1 - Injury frequency related to modalities

\begin{tabular}{|c|c|c|c|}
\hline Modality* & Injury type & Body Part & Specification \\
\hline $\begin{array}{l}\text { Soccer } \\
(255-23.4 \%)\end{array}$ & $\begin{array}{l}\text { - Joint }(150-59.8 \%) \\
\text { - Muscular }(77-30.7 \%) \\
\text { - Bone }(20-8.0 \%)\end{array}$ & $\begin{array}{l}\text { - Knee }(97-38.6 \%) \\
\text { - Ankle }(47-18.7 \%) \\
\text { - Thigh }(42-16.7 \%)\end{array}$ & $\begin{array}{l}\text { - Ankle Sprain }(36-17.8 \%) \\
\text { - Anterior Cruciate Ligament Injury }(28-13.9 \%) \\
\text { - Tendinopathy }(15-7.4 \%)\end{array}$ \\
\hline $\begin{array}{l}\text { Futsal } \\
(117-10.7 \%)\end{array}$ & $\begin{array}{l}\text { - Joint }(63-54.3 \%) \\
\text { - Muscular }(40-34.5 \%) \\
\text { - Bone }(12-10.3 \%)\end{array}$ & $\begin{array}{l}\text { - Knee }(38-32.8 \%) \\
\text { - Ankle }(22-19.0 \%) \\
\text { - Thigh }(16-13.8 \%)\end{array}$ & $\begin{array}{l}\text { - Ankle Sprain }(15-16.7 \%) \\
\text { - Anterior Cruciate Ligament Injury (10 - 11.1\%) } \\
\text { - Meniscal Knee Injury (7 - 7.8\%) }\end{array}$ \\
\hline $\begin{array}{l}\text { Track and field } \\
(117-10.7 \%)\end{array}$ & $\begin{array}{l}\text { - Joint }(64-56.1 \%) \\
\text { - Articular }(41-36.0 \%) \\
\text { - Bone }(8-7.0 \%)\end{array}$ & $\begin{array}{l}\text { - Thigh }(27-23.7 \%) \\
\text { - Lower Leg }(25-21.9 \%) \\
\text { - Knee }(24-21.1 \%)\end{array}$ & $\begin{array}{l}\text { - Tendinopathy }(13-15.3 \%) \\
\text { - Muscle Injury }(12-14.1 \%) \\
\text { - Medial Tibial Stress Syndrome }(8-9.4 \%)\end{array}$ \\
\hline $\begin{array}{l}\text { Basketball } \\
(79-7.2 \%)\end{array}$ & $\begin{array}{l}\text { - Joint }(37-48.7 \%) \\
\text { - Muscular }(27-35.5 \%) \\
\text { - Bone }(11-14.5 \%)\end{array}$ & $\begin{array}{l}\text { - Ankle }(19-25.0 \%) \\
\text { - Knee }(12-15.8 \%) \\
\text { - Lumbar spine }(8-10.5 \%)\end{array}$ & $\begin{array}{l}\text { - Ankle sprain }(14-22.2 \%) \\
\text { - Tendinopathy }(8-12.7 \%) \\
\text { - Low Back Pain }(4-6.3 \%)\end{array}$ \\
\hline $\begin{array}{l}\text { Volleyball } \\
(71-6.5 \%)\end{array}$ & $\begin{array}{l}\text { - Joint }(40-58.8 \%) \\
\text { - Muscular }(19-27.9 \%) \\
\text { - Bone }(8-11.8 \%)\end{array}$ & $\begin{array}{l}\text { - Knee }(17-25.0 \%) \\
\text { - Shoulder }(17-25.0 \%) \\
\text { - Ankle }(17-25.0 \%)\end{array}$ & $\begin{array}{l}\text { - Ankle sprain }(16-28.1 \%) \\
\text { - Tendinopathy }(7-12.3 \%) \\
\text { - Knee Chondropathy }(6-10.5 \%)\end{array}$ \\
\hline $\begin{array}{l}\text { Handball } \\
(56-5.1 \%)\end{array}$ & $\begin{array}{l}\text { - Joint }(33-61.1 \%) \\
\text { - Muscular }(18-33.3 \%) \\
\text { - Bone }(3-5.6 \%)\end{array}$ & $\begin{array}{l}\text { - Shoulder }(13-24.1 \%) \\
\text { - Knee }(10-18.5 \%) \\
\text { - Ankle }(10-18.5 \%)\end{array}$ & $\begin{array}{l}\text { - Ankle Sprain }(10-20.4 \%) \\
\text { - Tendinopathy }(6-12.2 \%) \\
\text { - Muscle Injury }(4-8.2 \%)\end{array}$ \\
\hline $\begin{array}{l}\text { Dance } \\
(46-4.2 \%)\end{array}$ & $\begin{array}{l}\text { - Joint }(21-52.5 \%) \\
\text { - Muscular }(14-35.0 \%) \\
\text { - Bone }(5-12.5 \%)\end{array}$ & $\begin{array}{l}\text { - Knee }(13-32.5 \%) \\
\text { - Ankle }(8-20.0 \%) \\
\text { - Lumbar spine }(5-12.5 \%)\end{array}$ & $\begin{array}{l}\text { - Ankle Sprain }(7-20.6 \%) \\
\text { - Tendinopathy }(4-11.8 \%) \\
\text { - Meniscal Knee Injury }(4-11.8 \%)\end{array}$ \\
\hline $\begin{array}{l}\text { Swimming } \\
(38-3.5 \%)\end{array}$ & $\begin{array}{l}\text { - Joint }(20-52.6 \%) \\
\text { - Muscular }(14-36.8 \%) \\
\text { - Bone }(2-5.3 \%)\end{array}$ & $\begin{array}{l}\text { - Shoulder }(11-28.9 \%) \\
\text { - Knee }(7-18.4 \%) \\
\text { - Ankle }(6-15.8 \%)\end{array}$ & $\begin{array}{l}\text { - Ankle Sprain }(5-17.2 \%) \\
\text { - Anterior Cruciate Ligament Injury }(5-17.2 \%) \\
\text { - Muscle Injury }(5-17.2 \%)\end{array}$ \\
\hline $\begin{array}{l}\text { Judo } \\
(35-3.2 \%)\end{array}$ & $\begin{array}{l}\text { - Joint }(23-65.7 \%) \\
\text { - Muscular }(11-31.4 \%) \\
\text { - Bone }(1-2.9 \%)\end{array}$ & $\begin{array}{l}\text { - Shoulder }(12-34.3 \%) \\
\text { - Knee }(6-17.1 \%) \\
\text { - Lumbar spine }(5-14.3 \%)\end{array}$ & $\begin{array}{l}\text { - Ankle Sprain }(5-17.9 \%) \\
\text { - Tendinopathy }(4-14.3 \%) \\
\text { - Muscle Injury }(3-10.7 \%)\end{array}$ \\
\hline $\begin{array}{l}\text { Jiu Jitsu } \\
(28-2.6 \%)\end{array}$ & $\begin{array}{l}\text { - Joint }(18-64.3 \%) \\
\text { - Muscular }(8-28.6 \%) \\
\text { - Bone }(1-3.6 \%)\end{array}$ & $\begin{array}{l}\text { - Knee }(8-28.6 \%) \\
\text { - Shoulder }(6-21.4 \%) \\
\text { - Thigh }(3-10.7 \%)\end{array}$ & $\begin{array}{l}\text { - Ankle Sprain }(2-9.15 \%) \\
\text { - Tendinopathy }(2-9.15 \%) \\
\text { - Medial Collateral Ligament Injury }(2-9.15 \%)\end{array}$ \\
\hline $\begin{array}{l}\text { Surf } \\
(27-2.5 \%)\end{array}$ & $\begin{array}{l}\text { - Joint }(15-55.6 \%) \\
\text { - Muscular }(8-29.6 \%) \\
\text { - Bone }(2-7.4 \%)\end{array}$ & $\begin{array}{l}\text { - Ankle }(7-25.9 \%) \\
\text { - Shoulder }(5-18.5 \%) \\
\text { - Knee }(4-14.8 \%)\end{array}$ & $\begin{array}{l}\text { - Ankle sprain }(5-23.8 \%) \\
\text { - Tendinopathy }(2-9.5 \%) \\
\text { - Shoulder Impact Syndrome }(2-9.5 \%)\end{array}$ \\
\hline $\begin{array}{l}\text { Triathlon } \\
(24-2.2 \%)\end{array}$ & $\begin{array}{l}\text { - Joint }(13-56.5 \%) \\
\text { - Muscular }(7-30.4 \%) \\
\text { - Bone }(3-13.0 \%)\end{array}$ & $\begin{array}{l}\text { - Knee }(7-30.4 \%) \\
\text { - Lower Leg }(4-17.4 \%) \\
\text { - Foot }(3-13.0 \%)\end{array}$ & $\begin{array}{l}\text { - Ankle sprain }(3-14.3 \%) \\
\text { - Plantar Fasciitis }(3-14.3 \%) \\
\text { - Knee Chondropathy }(3-14.3 \%)\end{array}$ \\
\hline
\end{tabular}

Note: ${ }^{*} 197$ athletes (18.2\%) were excluded from 32 different modalities.

\section{Discussion}

Athletes from 44 different modalities were assessed and treated by the program. The main result showed that the sports modality that presented the highest incidence of injuries was soccer, followed by indoor soccer and athletics. As for the types of injuries, joint injuries were the most frequent, mainly affecting knees and the ankles, while ankle sprain was the most common injury above all.

A study (20) has reported previously that soccer and futsal normally present the highest incidence of injuries; at the same time, these are among the most popular sports in the world, what makes any conclusion regarding their risks at least precipitated. According to the International Federation of Association Football (Fédération Internationale de Football Association - FIFA), in 2006 there were 265 million soccer players; $10 \%$ more than the last survey (from 2000). When women are taken into account this increase would amount to $50 \%$ (21). Soccer involves jumps, sprints, changes in direction, and a lot of contact and collisions: Muscle injuries such as hamstring tear have been shown and the as the most common 
among soccer players (20). Trauma caused by collision is also other very recurrent type of injury in soccer (22). Sousa (23) displayed the frequency of injuries in 251 amateur soccer players from 12 different teams during one season. At the end of the season 237 occurrences were reported (57\% of athletes); among them $11 \%$ were recurrent injuries, while $38 \%$ were a result of trauma due to contact with another player.

Players of contact sports such as soccer and indoor soccer are more prone to injuries. At the same time, joint injuries also appear in modalities that do not involve physical contact such as volleyball; in this case, physical contact is not the main cause of injuries but jump is (24-27). Jumping demands a lot of muscle power, at take off, and great joint stability to absorb the impact at the landing phase, where normal reaction force can reach values up to four times the body weight (26); such an impact may elicit several knee-related problems. For that reason, different prevention programs targeting volleyball have been discussed and recommended $(25,27)$. In addition to the impact against the knee, there are other types of injuries related to rotation and angulation of the joint (e.g. valgus/varus deformity) (28). These findings corroborate the results of the current study.

Similar to knee, ankle is also susceptible to injuries resulting from rapid movements especially the movements toward the direction favoring the exacerbation of ankle inversion $(29,30)$. The ankle is also greatly demanded while jumping and landing (31). Despite the fact that the current study identified the ankle as the second most affected joint, ankle sprain was the most common injury in our records. A systematic review by Fong et al. (29) showed that almost $25 \%$ of all sports injuries were ankle sprains. This expressive incidence might be explained by the anatomy of the ankle (30): this joint has many degrees of freedom what makes ankle more prone to injuries. Ankle and foot are also subject to training overload that leads repetitive-strain injuries such as stress fractures, plantar fasciitis and tendinopathies (32).

Our results also showed high incidence joint injuries compared to muscle injuries. However, in track and field the muscular happened more often. Athletics encompasses several other sports modalities that have different demands and therefore might elicit different types of injury (33). Other study, which analyzed only track and field competitions, also considered the muscle injuries the most frequent (34). The authors attributed their results to muscle imbalance, flexibility, fatigue, age, and presence of previous injuries (34). Another possibility is the abrupt change between eccentric and concentric action that might increase the risk of injuries during such movements (35). Alonso et al. (34) also pointed out that exposure time is another factor that might paly a role in overuse injuries in long distance runners.

\section{Study Limitations}

Despite the large number of athletes, care should be taken when analyzing the results of the current study since our data is only composed of athletes who sought treatment. Hence, our results do not specifically reflect the incidence of injury by sport. Another limitation relates to the fact that, besides being a public service, it is possible that injuries the athletes considered less important might not have been reported. This could explain why muscle injuries that are normally more frequent were not the largest number in the current study. Taking this into account, the lack of records of previous injuries can also be considered a limitation. Another point is the high rates of chronic injuries that can be a result of overuse or even attributed to the insistence and reluctance of the athletes to interrupt their practice in order to properly treat their injuries. On the other hand, the athletes' demand for treatment is well represented from what they believe to be important to interrupt their training.

\section{Conclusion}

The great majority of the athletes assessed were soccer, indoor soccer players, and athletics practitioners. The most frequent type injury was the jointrelated injury followed by muscle, and bone. Athletes with chronic injuries were the ones who sought the most our program and although the knee was the most affected joint, the ankle sprain was the most frequent injury. Further studies on sports injury incidence and surveys on injuries frequently omitted by the athletes would be also interesting.

\section{Acknowledgments}

The authors would like to thank all the students and faculty that contributed to the Sport Physiotherapy 
extension program from Universidade do Estado de Santa Catarina, especially the physiotherapist Vanessa Kume for assisting the data collection.

\section{References}

1. Taanila H, Suni JH, Kannus P, Pihlajamäki H, Ruohola J-P, Viskari J, et al. Risk factors of acute and overuse musculoskeletal injuries among young conscripts: a population-based cohort study. BMC Musculoskelet Disord. 2015;16:104.

2. Freckleton G, Pizzari T. Risk factors for hamstring muscle strain injury in sport: a systematic review and meta-analysis. Br J Sports Med. 2013;47(6):351-8.

3. Janssen I, LeBlanc AG. Systematic review of the health benefits of physical activity and fitness in schoolaged children and youth. Int J Behav Nutr Phys Act. 2010;7:40.

4. Vancini RL, Lira CAB, Scorza FA, Arida RM. Benefícios e riscos da prática de atividade física recreativa e/ou esportiva por pessoas com epilepsia. Fisioter Mov. 2011;24(2):347-55.

5. Cassell E, Finch C, Stathakis V. Epidemiology of medically treated sport and active recreation injuries in the Latrobe Valley, Victoria, Australia. Br J Sports Med. 2003;37(5):405-9.

6. Tenan MS. Quantifying emergency department visits from sport and recreation: focus on the lower extremity and knee, 1997-2009. J Athl Train. 2016;51(4):309-16.

7. Pangrazio 0, Forriol F. Epidemiology of injuries sustained by players during the 16th Under-17 South American Soccer Championship. Rev Esp Cir Ortop Traumatol. 2016;60(3):192-9.

8. Pierpoint LA, Williams CM, Fields SK, Comstock RD. Epidemiology of injuries in United States high school track and field: 2008-2009 through 2013-2014. Am J Sports Med. 2016;44(6):1463-8.

9. Lopes AD, Hespanhol Jr LC, Yeung SS, Costa LOP. What are the main running-related musculoskeletal injuries? A systematic review. Sports Med. 2012;42(10):891-905.
10. Moraes GC, Guimarães ATB, Gomes ARS. Análise da prevalência de lesões em surfistas do litoral paranaense. Acta Ortop Bras. 2013;21(4):213-8.

11. Almeida Neto AF, De AF, Tonin JP, Navega MT. Caracterização de lesões desportivas no basquetebol. Fisioter Mov. 2013;26(2):361-8.

12. Bahr R, Krosshaug T. Understanding injury mechanisms: a key component of preventing injuries in sport. Br J Sports Med. 2005;39(6):324-9.

13. Soomro N, Sanders R, Hackett D, Hubka T, Ebrahimi $\mathrm{S}$, Freeston J, et al. The efficacy of injury prevention programs in adolescent team sports: a meta-analysis. Am J Sports Med. 2015;44(9):2415-24.

14. DiStefano LJ, Marshall SW, Padua DA, Peck KY, Beutler AI, de la Motte SJ, et al. The effects of an injury prevention program on landing biomechanics over time. Am J Sports Med. 2016;44(3):767-76.

15. Christakou A, Lavallee D. Rehabilitation from sports injuries: from theory to practice. Perspect Public Health. 2009;129(3):120-6.

16. Kume V, Haupenthal A, Nunes GS, Mannrich G, Haupenthal DS, Wageck B. Subjective criteria associated with return-to-play in sports physical therapy. Fisioter Mov. 2015;28(3):501-7.

17. Fuller CW, Ekstrand J, Junge A, Andersen TE, Bahr $\mathrm{R}$, Dvorak J, et al. Consensus statement on injury definitions and data collection procedures in studies of football (soccer) injuries. Br J Sports Med. 2006;40(3):193-201.

18. Fuller CW, Molloy MG, Bagate C, Bahr R, Brooks JHM, Donson $\mathrm{H}$, et al. Consensus statement on injury definitions and data collection procedures for studies of injuries in rugby union. Br J Sports Med. 2007;41(5): 328-31.

19. Knight KL. More precise classification of orthopaedic injury types and treatment will improve patient care. J Athl Train. 2008;43(2):117-8.

20. Dauty M, Collon S. Incidence of injuries in French professional soccer players. Int J Sports Med. 2011;32(12):965-9.

21. Stamm H, Lamprecht M. Big Count. Football 2006 Worldwide: Official FIFA Survey. Zurich: FIFA, 2007. [cited 2012 Jun 29]. Available from: < https://goo. gl/keqRvv>. 
22. Brito J, Malina RM, Seabra A, Massada JL, Soares JM, Krustrup P, et al. Injuries in Portuguese youth soccer players during training and match play. J Athl Train. 2012;47(2):191-7.

23. Sousa P. Incidência de lesões em jogadores amadores de futebol: estudo prospectivo ao longo de uma época desportiva [master's thesis]. Porto: Universidade do Porto; 2011.

24. Bates NA, Ford KR, Myer GD, Hewett TE. Kinetic and kinematic differences between first and second landings of a drop vertical jump task: implications for injury risk assessments. Clin Biomech (Bristol, Avon). 2013;28(4):459-66.

25. Myer GD, Stroube BW, DiCesare CA, Brent JL, Ford KR, Heidt RS, et al. Augmented feedback supports skill transfer and reduces high-risk injury landing mechanics: a double-blind, randomized controlled laboratory study. Am J Sports Med. 2013;41(3):669-77.

26. McClay IS, Robinson JR, Andriacchi TP, Frederick EC, Gross T, Martin P, et al. A profile of ground reaction forces in professional basketball. J Appl Biomech. 1994;10(3):222-36.

27. Favre J, Clancy C, Dowling AV, Andriacchi TP. Modification of knee flexion angle has patient-specific effects on anterior cruciate ligament injury risk factors during jump landing. Am J Sports Med. 2016;44(6):1540-6.

28. Nordenvall R, Bahmanyar S, Adami J, Stenros C, Wredmark T, Felländer-Tsai L. A population-based nationwide study of cruciate ligament injury in Sweden, 2001-2009 incidence, treatment, and sex differences. Am J Sports Med. 2012;40(8):1808-13.

29. Fong DT, Chan Y-Y, Mok K-M, Yung PS, Chan K-M. Understanding acute ankle ligamentous sprain injury in sports. Sports Med Arthrosc Rehabil Ther Technol. 2009;1:14.
30. Hertel J. functional anatomy, pathomechanics, and pathophysiology of lateral ankle instability. J Athl Train. 2002;37(4):364-75.

31. Norcross MF, Blackburn JT, Goerger BM, Padua DA. The association between lower extremity energy absorption and biomechanical factors related to anterior cruciate ligament injury. Clin Biomech (Bristol, Avon). 2010;25(10):1031-6.

32. Sobhani S, Dekker R, Postema K, Dijkstra PU. Epidemiology of ankle and foot overuse injuries in sports: A systematic review. Scand J Med Sci Sports. 2013;23(6):669-86.

33. Pastre CM, Carvalho Filho G, Monteiro HL, Netto Jr J, Padovani CR. Sports injuries in Brazilian elite of the athletics: study based on referred morbidity. Rev Bras Med Esporte. 2005;11(1):43-7.

34. Alonso J-M, Edouard P, Fischetto G, Adams B, Depiesse F, Mountjoy M. Determination of future prevention strategies in elite track and field: analysis of Daegu 2011 IAAF Championships injuries and illnesses surveillance. Br J Sports Med. 2012;46(7):505-14.

35. Ekstrand J, Hägglund M, Waldén M. Epidemiology of muscle injuries in professional football (soccer). Am J Sports Med. 2011;39(6):1226-32.

Received in 03/31/2016

Recebido em 31/03/2016

Approved in 03/03/2017

Aprovado em 03/03/2017 